\title{
Advances in immunotherapy for acute myeloid leukemia
}

\author{
Amanda Przespolewski ${ }^{1}$, Andras Szeles ${ }^{1,2}$ \& Eunice S Wang*,1 \\ ${ }^{1}$ Leukemia Service, Department of Medicine, Roswell Park Comprehensive Cancer Center, Buffalo, NY 14263, USA \\ ${ }^{2}$ Semmelweis University, Budapest, Üllői út 26, 1085, Hungary \\ * Author for correspondence: Fax: +1 716845 8741; Eunice.wang@roswellpark.org
}

Evasion of the host immune system is a key mechanism to promote malignant progression. Therapeutically targeting immune pathways has radically changed the treatment paradigm for solid and lymphoid tumors but has yet to be approved for myeloid malignancies. Here, we summarize the most recent advances in immunotherapy for acute myeloid leukemia. Topics reviewed here include adoptive cellular approaches (chimeric antigen receptor-T cells, natural killer and other immune cells), checkpoint inhibitors (anti-PD1/PD-L1, anti-CTLA-4 and TIM-3) and vaccines (WT-1, HLA-A2 and hTERT). Emphasis is placed on agents with clear evidence of tumor-specific immune responses and/or clinical activity in early-phase trials. Despite concerns regarding heterogeneous antigen expression and cytokine release syndrome, immunotherapy remains a highly promising strategy for acute myeloid leukemia, particularly transplant-ineligible patients and minimal residual disease states.

First draft submitted: 12 September 2017; Accepted for publication: 6 December 2017; Published online: 15 March 2018

Keywords: AML $\bullet$ CART cell $\bullet$ checkpoint inhibitor $\bullet$ dendritic cell $\bullet$ immunotherapy $\bullet$ NK cell $\bullet$ vaccine therapy

Novel therapeutic strategies are needed for the treatment of acute myeloid leukemia (AML), a clonal hematopoietic stem cell disorder anticipated to affect 21,380 Americans in 2017. Only $26.9 \%$ are expected to survive beyond 5 years. Standard of care chemotherapy consisting of cytarabine and an anthracycline (termed $7+3$ ) is often difficult to tolerate, particularly in older individuals who comprise the majority of patients, and is associated with high relapse rates [1]. Over the past decade, immunotherapy (defined as the generation of an efficacious anti-tumor immune response [IR]) has revolutionized treatment of multiple solid tumors and lymphoid malignancies [2]. Here we review the most recently available literature on immunotherapy for the treatment of AML. Therapeutic modalities discussed here include adoptive cellular approaches, checkpoint inhibitors and vaccines.

\section{CART therapy}

The recent approvals of CART therapy in the USA for pediatric acute lymphocytic leukemia and aggressive B-cell lymphoma has spurred on similar efforts to engineer CART for AML. In brief, CART are defined as autologous $T$ cells, which are genetically modified to express the single variable chains (variable light chain [VL] and variable heavy chain $[\mathrm{VH}]$ plus a linker) of antibodies expressed on the surface of cancer cells. These extracellular domains are fused to $\mathrm{CD} 3 \zeta$, the intracellular signaling domain of the T-cell receptor (first-generation CART) and one or more co-stimulatory domains (CD28 and/or 41BB in second- and third-generation CART), as well as inducible expression cassettes for transgenic proteins (i.e., IL-2; fourth-generation CART) (Figure 1) [3]. One challenge with the development of effective broad spectrum CART for AML is the biological heterogeneity of this myeloid neoplasm based on the different myeloid progenitors from which it arises. Multiple targets in development for directed CART therapy in AML include CD33, CD123, FR $\beta$, CLL1 or CLEC12A, FLT3, B7H6, NKG2D and Lewis Y (LeY) [4-9]. These CART-directed therapies are described below based on evidence of their significant in vitro and in vivo activity against antigen-expressing AML targets.

Future Medicine 


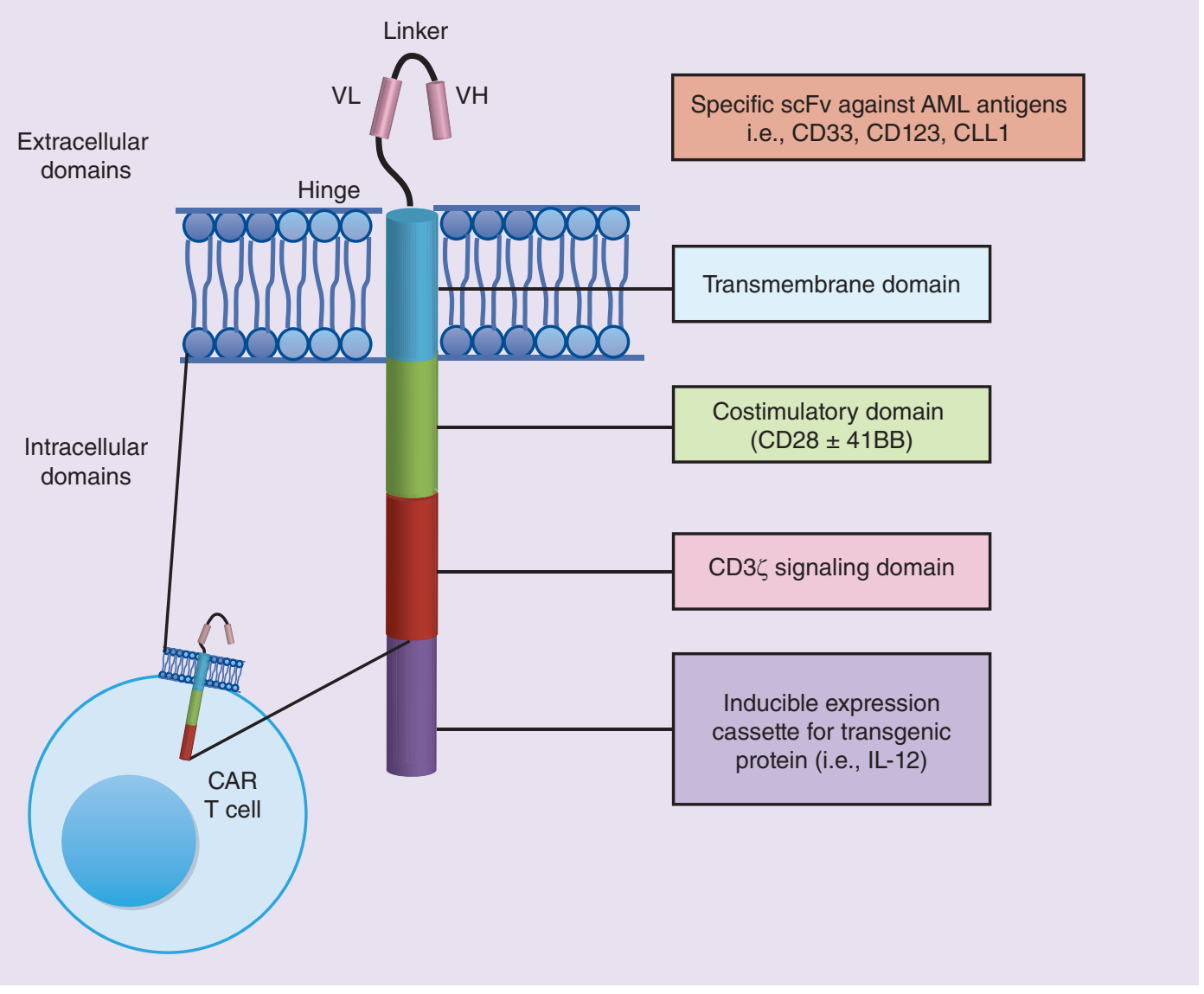

Figure 1. Structure of CARTs for acute myeloid leukemia therapy.

AML: Acute myeloid leukemia; VH: Variable heavy chain; VL: Variable light chain.

\section{CD33 CARTs}

CD33 is a sialic acid-binding transmembrane receptor expressed on $>90 \%$ of AML blasts, early multilineage hematopoietic progenitors, myelomonocytic precursors, and to a limited extent, pluripotent stem cells and nonhematologic tissues [10]. Validation of CD33 as a therapeutic target has long been recognized based on the clinical efficacy of gemtuzumab ozogamicin, an approved anti-CD33 antibody-drug conjugate for CD $33^{+}$AML patients. Numerous constructs have been employed to generate CD33-targeted CART (CART-33). Kenderian et al. designed CART-33 expressing a humanized version of the single-chain variable fragment $(\mathrm{scFv})$ of the original murine anti-hCD33 clone [11]. Rafiq et al. generated CART-33 expressing variable light and heavy chains of the humanized M-195 antibody along with co-stimulatory CD28 and CD3 $\zeta$ signaling domains and an inducible IL-12 gene [12]. Co-culture of CART-33 with AML blasts resulted in enhanced IFN- $\gamma$, IL-2 and IL-12 production. O'Hear $e$ al . engineered CART-33 cells expressing a CD33 scFv linked to a CD8 leader sequence and 4-1BB and CD3 $\zeta$ costimulatory domains [13]. Across all of the studies, CART-33 consistently proliferated in vitro, produced marked levels of cytokines and exert robust cytotoxicity when co-cultured with $\mathrm{CD} 33^{+} \mathrm{AML}$ cells at low effector:target ratios. In addition, infusion of each CART-33 consistently eradicated disease and prolonged overall survival (OS) in primary $\mathrm{CD}_{3} 3^{+} \mathrm{AML}$ xenograft models [11-13]. Another interesting CART-33 formulation has been developed specifically to address the risk of potentially life-threatening cytokine release syndrome (CRS). Minagawa et al. modified human T-cells to express an inducible CASP9 suicide gene, a selectable marker and a humanized thirdgeneration CAR recognizing human CD33. These CASP9/CD33 modified CART specifically lysed CD $33^{+}$targets in vitro, produced significant levels of cytokines and proliferated well. Administration of a non-therapeutic dimerizer triggering the suicide gene resulted in eradication of $76 \%$ of gene-modified cells in culture [14].

Many of these CART-33 formulations are planned to undergo clinical validation (Table 1). To date, data on clinical efficacy has yet to be widely reported. Wang et al. reported the efficacy and tolerability of CART-33 for a 


\begin{tabular}{|c|c|c|c|c|c|}
\hline Study & Antigen target & Construct & In vivo effects & Stage of development & Ref. \\
\hline Wang et al. & CD33 & Autologous, unavailable & $\begin{array}{l}\text { Cytotoxicity against } K 562, \\
\text { cytolytic against } \mathrm{HL} 60 \text { and } \\
\text { primary pts samples }\end{array}$ & Case report, Phase I, II & [15] \\
\hline $\mathrm{N} / \mathrm{A}$ & CD123 & UCAR123, not available & $\begin{array}{l}\text { Effective elimination of AML cell } \\
\text { lines }\end{array}$ & Phase I, in recruitment & \\
\hline Nikiforow et al. & NKG2D & Not available & Not available & Phase I & [21] \\
\hline Peinert et al. & LeY & Not available & $\begin{array}{l}\text { Cytolytic activity and IFN-Y } \\
\text { production when co-cultured } \\
\text { with AML cell lines and primary } \\
\text { pts samples }\end{array}$ & Phase I & [22] \\
\hline Wang et al. & Not available & $\begin{array}{l}\text { Autologous CIK-cell infusion, } \\
\text { derived from recurrent or } \\
\text { refractory AML pts }\end{array}$ & $\begin{array}{l}\text { One patient with dramatic } \\
\text { reduction in leukemic burden }\end{array}$ & Phase I & [44] \\
\hline Rettinger et al. & Not available & IL-15 activated CIK cell infusion & $\begin{array}{l}\text { Four out of ten patients } \\
\text { undergoing CIK infusion with } \\
\text { MRD sustained a molecular } \\
\text { response }\end{array}$ & Phase I & [45] \\
\hline Kunzmann et al. & $N / A$ & $\begin{array}{l}\text { Autologous ex vivo expanded } \\
\text { gamma delta T lymphocytes }\end{array}$ & $\begin{array}{l}\text { Two AML pts in PR; pts had in } \\
\text { vivo expansion and activation }\end{array}$ & Phase I/II & [49] \\
\hline
\end{tabular}

single patient with refractory AML [15]. A total of $1.12 \times 10^{9}$ CART-33 cells were administered in escalating doses over 4 consecutive days without conditioning. Following infusion, the patient experienced a marked decrease in blasts from $>50 \%$ pretreatment to $<6 \%$ at 2 weeks following administration. Despite persistently high levels of CART and elevations in multiple immunomodulatory cytokines (IL-6, IL-8, TNF- $\alpha$ and IFN- $\gamma$ ) in the peripheral blood, the blast percentage gradually increased to nearly $70 \%$ at 9 weeks postinfusion consistent with tumor escape. The patient ultimately succumbed to his disease at 13 weeks. Toxicities included grade 4 chills, fevers up to $42^{\circ} \mathrm{C}$ treated with etanercept (anti-TNF- $\alpha$ ) and transient hyperbilirubinemia. Two ongoing clinical trials in China are underway. In NCT01864902, Wang et al. will evaluate the safety and in vivo persistence of autologous or donor-derived CART-33 cells in refractory/relapsed AML. The second trial (NCT02799680) is evaluating the safety and efficacy of allogeneic CART-33 cells in similar patients [16].

\section{CD123 CART}

CD123, a transmembrane $\alpha$ subunit of the IL-3 receptor expressed on AML blasts, represents another attractive immunotherapeutic target [17]. Multiple CD123-directed CART (CART-123) constructs have exhibited significant cytotoxicity against CD123-expressing AML cell lines and primary samples [18,19]. In addition, CART-123 has induced increased IFN- $\gamma$, MIP $1 \alpha$, MIP1 $\beta$, IL-2 and GM-CSF levels. In vivo T cells expressing these CAR constructs decreased disease burden in $\mathrm{CD} 123^{+}$AML cell lines and primary patient xenografts. Based on these preclinical results, multiple clinical trials evaluating CART-123 T cells in AML patients are now recruiting. A Phase I trial for UCART123 recently began enrolling patients with relapsed or refractory AML (NCT03190278) but was placed on clinical hold in September 2017 by the US FDA after a patient with relapsed blastic plasmacytoid dendritic cell (DC) neoplasm, another rare $\mathrm{CD} 123^{+}$hematological malignancy, died due to severe CRS only 9 days receiving experimental CART-123 infusion [20]. The hold was released on 7 November 2017, following the implementation of several provisions within the trial, including decreased CART-123 dose levels, decreased dose of cyclophosphamide used as lymphodepletion and more stringent criteria regarding active infection, organ dysfunction and age. Another Phase I dose escalation study evaluating the safety, tolerability and optimal dosing of anti-CD123/CD28 CART cells co-expressing truncated EGFR is underway (NCT02159495). Another trial is evaluating donor-derived CART-123 cells in relapsed AML following allogeneic transplant (NCT03114670).

\section{NKG2D CART}

NKG2D ligands upregulated on cell surface of malignant hematopoietic cells have also served as targets for AMLdirected CART. A pilot trial detailing the results of six patients with AML or myelodysplastic syndrome (MDS) who received NKG2D-targeted CART demonstrated that single dose infusions were overall well tolerated with no dose-limiting toxicities (DLTs) or cytokine release. Single dosing, however, resulted in no clinical leukemic responses 
up to 28 days after infusion. Future studies investigating the efficacy of multiple CART-NKG2D infusions are planned [21].

\section{FR $\beta$ targeting}

FR $\beta$, a cell membrane-bound folate receptor with homology with folate receptor $\alpha$, is expressed in $70 \%$ of primary AML cases with relatively limited expression in normal tissue. CART generated with $\mathrm{m} 909 \mathrm{scFv}$ designed FR $\beta$ specific CAR constructs resulted in more significant IFN- $\gamma$ release responses when exposed to FR $\beta$-positive AML targets than controls. These m909 CART cells proliferated, exerted potent in vitro lysis of AML cells in co-culture and demonstrated promising in vivo anti-leukemic activity [4].

\section{Human CLL1 targeting}

Although CLL1 (or CLEC12A) is also overexpressed in AML blasts and stem cells, to date, CLL1-targeted CART have exhibited only modest effector function against primary AML cells, likely due to heterogeneous surface expression. However, because CLL1 is preferentially overexpressed in refractory AML cells in the marrow following induction chemotherapy, these CART-CLL1 cells may constitute an effective means of eradicating minimal residual disease (MRD). Mice engrafted with primary human AML and treated with cytarabine followed by a single dose of CART-CLL1 had significantly longer survival than non-transduced mice receiving chemotherapy alone [5,6].

\section{FLT3 targeting}

AML cells and hematopoietic progenitors typically express high levels of the FLT3 receptor independent of FLT3 gene mutation status, leading to significant interest as a therapeutic target for CART-directed AML therapy. T cells were transduced with a FLT3 CAR construct consisting of an scFv from an established anti-human FLT3 antibody paired with $41 \mathrm{BB}$ and a CD3 3 costimulatory domains. These CART-FLT3 cells demonstrated promising in vitro and in vivo antileukemic effects. Of note, comparison of CART-FLT3 with CART-33 cells revealed that CART-FLT3-transduced cells exhibited potentially less toxicity to normal hematopoietic progenitors than their CD33 counterparts, a potential therapeutic advantage [7].

\section{B7H6 targeting}

B7H6, a member of the B7 family recognized by NKp30, an activating receptor on NK cells, is readily detectable on AML blasts but not on healthy tissue. CART expressing NKp30 elicited B7H6-dependent potent cytolytic activity and IFN- $\gamma$ release when co-cultured with various leukemia cell lines and primary blasts, but not with B7H6-negative myeloma lines. AML-engrafted mice infused with NKp30-positive CART exhibited appreciable reduction in tumor burden. In vivo CART-NKp30 treatment was particularly effective in eradicating MRD [8].

\section{LeY targeting}

LeY antigen is also overexpressed on AML cells with limited normal tissue expression. Preclinical studies have demonstrated that LeY-specific CART (CART-LeY) produced varying amounts of IFN- $\gamma$ on exposure to AML cells and resulted in cytolytic activity [22]. A Phase I trial (NCT01716364) treated patients with relapsed AML with fludarabine and cytarabine followed by CART-LeY infusion. Out of four evaluable patients, one achieved a transient cytogenetic remission (5 months), one experienced a transient reduction in peripheral blasts and one had stable disease (SD) for 23 months. No grade $3 / 4$ adverse events or CRS were observed. Although all patients eventually relapsed, the persistence of detectable CART-LeY cells for up to 10 months after infusion supports the promise of this approach [23].

\section{Natural killer cell therapy}

Natural killer (NK) cells play an early role in recognizing self versus nonself and eradicating tumors via perforin production, cytokine release and antibody-dependent cell-mediated cytotoxicity. In addition, anti-tumor NK cell activity is partially mediated by stimulation of TNF-related apoptosis-inducing ligand on these cells in an IFN- $\gamma$ dependent manner [24]. Based on compelling evidence that NK activity is drastically altered in leukemic conditions, multiple immunotherapeutic strategies directed at enhancing effective NK cell function are being prospectively evaluated as AML therapy (Table 2) [25]. Approaches to enhance the clinical efficacy of allogeneic NK cells include: using NK cells in conjunction with allogeneic stem cell transplant (alloSCT); improving delivery of a diverse NK 


\begin{tabular}{|c|c|c|c|c|}
\hline Study & Construct & In vivo effects & Stage of development & Ref. \\
\hline Kottaridis et al. & CNDO-109-activated allogenic NK cells & $\begin{array}{l}\text { Four out of seven patients remained in } C R \text { for } \\
\text { longer periods post-treatment than their prior } C R\end{array}$ & Phase I & [25] \\
\hline Lee et al. & Haploidentical NK cell transplant & $\begin{array}{l}\text { Tolerability comparable to HSC transplant; modest } \\
\text { survival benefit }\end{array}$ & Phase I & [27] \\
\hline Shaffer et al. & Haploidentical NK cell infusion & Good tolerability; no survival benefit & Phase II & [28] \\
\hline Curti et al. & $\begin{array}{l}\text { Haploidentical NK cell infusion from KIR-ligand } \\
\text { mismatched donors }\end{array}$ & $\begin{array}{l}\text { Relapse-free duration associated with increased } \\
\text { number of alloreactive NK cell clones received }\end{array}$ & Phase I & [29] \\
\hline Romee et al. & HLA haploidentical CIML-NK cell infusion & $\begin{array}{l}\text { Robust donor NK cell proliferation and IFN- } \gamma \\
\text { production }\end{array}$ & Phase I & [32] \\
\hline Dolstra et al. & $\begin{array}{l}\text { Partially HLA-matched NK cells derived from } \\
\text { umbilical cord progenitors }\end{array}$ & $\begin{array}{l}\text { Five out of nine evaluable patients in CR of } \\
\text { variable duration (range: } 4-43 \text { months) }\end{array}$ & Phase I & [33] \\
\hline Boyiadzis et al. & Two sequential aNK infusions & $\begin{array}{l}\text { Two out of seven patients with refractory AML } \\
\text { showed stable blast } \% \text {, one out of seven with } \\
\text { reduction in blast count }\end{array}$ & Phase I & [35] \\
\hline
\end{tabular}

AML: Acute myeloid leukemia; aNK: Activated natural killer cell; CIML-NK: Cytokine-induced memory-like natural killer; CR: Complete remission; HLA: Human leukocyte antigen; HSC: Hematopoietic stem cell; KIR: Killer immunoglobulin-like receptor; NK: Natural killer.

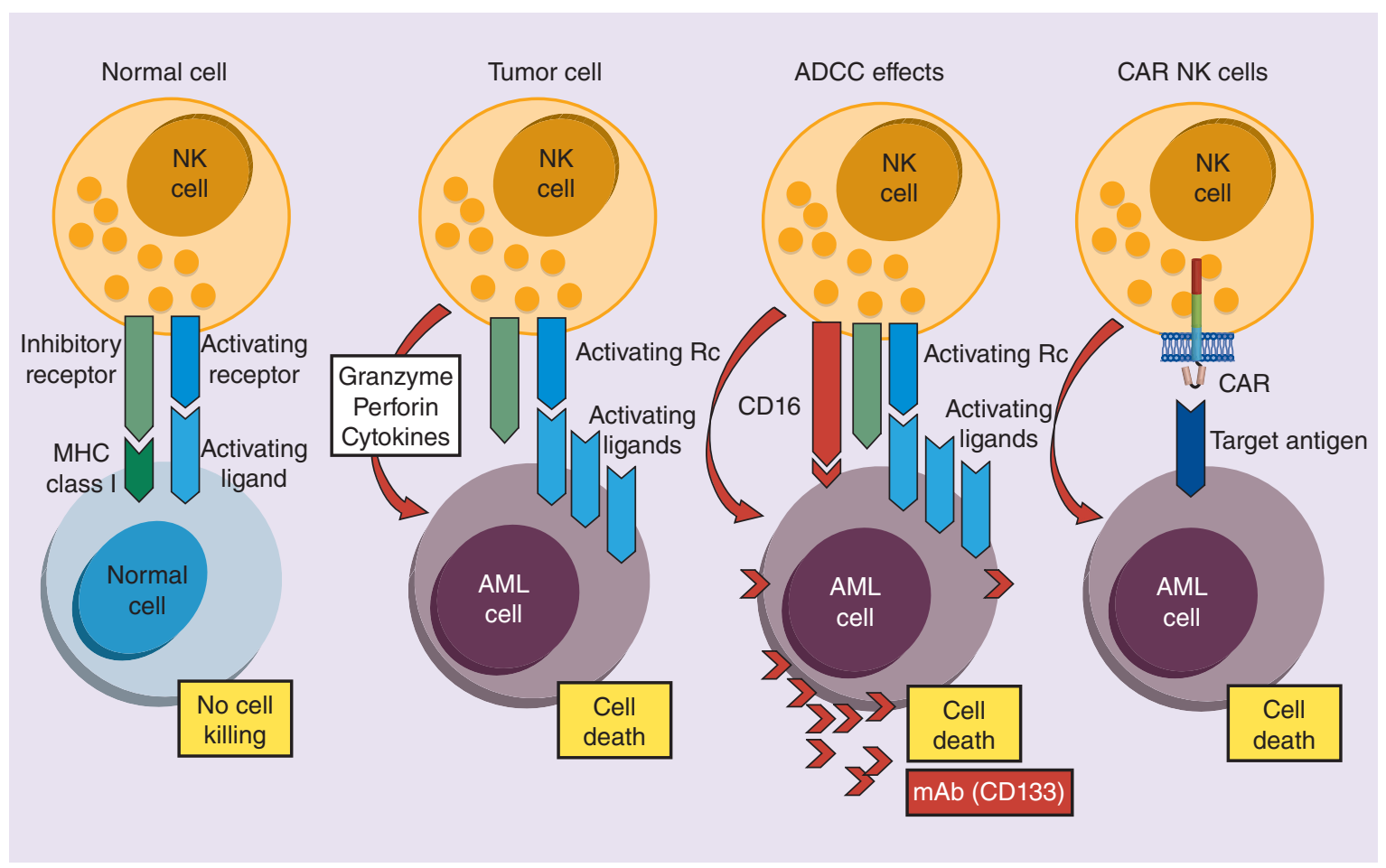

Figure 2. Natural killer cell therapy for acute myeloid leukemia.

AML: Acute myeloid leukemia; NK: Natural killer.

cell repertoire and/or functional subsets; activation or priming of NK cells to induce greater anti-cancer activity; and generation of autologous NK cells with CART constructs (see Figure 2 for examples).

\section{Allogeneic NK cell therapy plus hematopoietic stem cell transplant}

Multiple groups have evaluated the efficacy of in vitro expanded allogeneic NK cells administered in conjunction with alloSCT in AML patients. Alloreactive NK cells are known to exert a cytotoxic response against neoplastic cells in the context of transplant by improving engraftment and mediating graft versus leukemia (GVL) activity [26]. In a recently published Phase I study, 21 patients with myeloid malignancies received haploidentical NK cell administration after conditioning with busulfan, fludarabine and prior to alloSCT from another donor [27]. No increased incidence of serious acute graft versus host disease (GVHD; 10\%) was noted. Although an OS benefit 
was uncertain (median survival $=223$ days [range: 8-2251]), the investigators claim that the duration of response correlated with $\mathrm{CD} 56^{+} \mathrm{NK}$ cell dosage, with a trend toward improved survival in killer immunoglobulin-like receptors-mismatched NK cells. Haploidentical NK cell infusion after immunosuppression with cyclophosphamide and fludarabine is also currently being investigated in a Phase II trial in Germany for individuals $>65$ years old ineligible for conventional alloSCT (NCT02229266). Haploidentical NK cells are also being investigated for relapsed/refractory AML (RR-AML). Eight patients with AML or MDS following prior alloSCT received lymphodepletion followed by donor NK cell infusion and IL-2 [28]. Although one patient experienced remission, no survival benefit was observed and no donor NK cells were detected in patients. A Phase IIb study in Korea is evaluating the effects of donor NK cell infusion on day +13 and +20 after alloSCT for RR-AML (NCT02477787). Clinical responses to haploidentical NK cells appear to correlate with NK cell repertoire in recipients [29]. Among 17 patients in morphologic complete remission, those who received more than eight of 100 alloreactive NK clones demonstrated an improved mean relapse-free survival (RFS; 43 vs 21.6 months in patients with less than eight of $100 \mathrm{NK}$ clones). Björklund et al. demonstrated that pretransplant NK cell repertoires containing high frequencies of immature NK cell phenotypes (NKG2A+, NKG2C- NK cells) were associated with reduced relapse but also notably higher incidences of infection-related mortality after transplant [30].

\section{Cytokine-induced memory-like NK cells}

As compared with other NK cells, cytokine-induced memory-like (CIML) NK cells pre-activated by IL-12, IL-15 and IL-18 exhibited enhanced cytotoxicity, increased expression of granzyme B, and more robust IFN- $\gamma$ production during restimulation with primary AML blasts. In addition, CIML demonstrated more robust responses to restimulation by cytokines and receptor triggered activation [31] and can be identified based on distinctive surface markers [32]. Infusion of CIML into AML-engrafted mice reduced AML burden and improved survival as compared with mice receiving control NK cells. Based on these findings, the investigators conducted a first-in-human trial with allogeneic HLA haploidentical CIML-NK cells infused into patients with RR-AML [32]. Nine patients received preconditioning followed by infusion of pre-activated memory-like NK cells at three escalating doses. Because of concerns about CRS, donor cells were dosed at $1 / 10-1 / 20$ th of prior adoptive allogeneic NK cell doses. Donor NK cells robustly proliferated in vivo with over 400 -fold increase within 1 week and accounted for $>90 \%$ of total peripheral NK cells. Cells isolated from recipient blood also showed robust IFN- $\gamma$ production. The overall response rate was $55 \%$ with four of nine patients achieving a $\mathrm{CR}$ or $\mathrm{CR}$ with incomplete count recovery (CR/CRi). Further enrollment is ongoing (NCT01898793).

\section{Alternative sources of NK cells}

The development of 'off the shelf' NK cell products as ready sources of adoptive immunotherapy for AML has garnered much interest. For instance, normal hematopoietic progenitor cells isolated from umbilical cord blood (UCB), bone marrow or GM-CSF mobilized blood have been shown to be a reliable source for further ex vivo NK cell expansion. The safety and toxicity of NK cell infusions arising from UCB-derived CD $34^{+}$progenitors was recently evaluated in a Phase I dose escalation study involving 12 older patients with AML in morphologic CR and ineligible for alloSCT [33]. Patients received lymphodepletion followed by infusion of partially HLA-matched UCB-derived NK cells. Five of nine evaluable patients remained in CR (56\%) after 43, 35, 31, 5 and 4 months, respectively. Interestingly, the UCB-derived NK cells appeared to expand and migrate to recipient bone marrow without supplemental IL-2. The safety and efficacy of UCB-derived NK cell infusion after alloSCT for multiple hematologic malignancies, including AML is currently being explored (NCT01619761).

Recently non-IL-2 primed allogeneic NK cells and NK cells derived from an immortalized human NK cell line have also been developed. In the first paradigm, lysate from the CTV-1 cell line (originally derived from an AML patient) was incubated with NK cells derived from close patient relatives, resulting in effective allogeneic NK cells (CNDO-109-activated allogenic NK cells or AANKs) capable of in vitro destruction of NK resistant tumors. In a Phase I trial, seven AML patients received a preparatory regimen of fludarabine and total body irradiation followed by single infusion of primed CNDO-109 AANKs [25]. Despite a high incidence of significant myelosuppression, patients had a median survival of 400 days (range: 141-910) with four out of seven remaining in CR for longer duration than following previous chemotherapy. A Phase I/II study evaluating escalating doses of CNDO-109 AANKs for AML patients in first remission is currently underway (NCT01520558). Preliminary results have reported three out of 12 patients to have RFS durations of 22-27 months [34]. In addition, activated NK (aNK) cells generated from an IL-2-dependent human NK cell line (NK-92) have also undergone clinical 
evaluation. An ongoing Phase I trial of aNK in seven adult patients with RR-AML treated with two infusions of 1 to $3 \times 10^{9}$ cells $/ \mathrm{m}^{2}$ demonstrated no significant toxicities and clinical disease improvement in three patients (NCT00900809) [35].

\section{Antibody-mediated enhancement of NK cell activity}

Because NK cells are also capable of antibody-dependent cellular cytotoxicity, monoclonal antibodies (mAbs) have been used to further activate NK cells to improve antileukemic activity (Figure 2). Treatment with an Fc-optimized anti-CD133 mAb successfully activated CD16 ${ }^{+}$-positive NK cells and resulted in enhanced lytic activity against CD133-positive AML cells in vitro with limited effects on normal hematopoietic progenitors. Antibody-activated NK cells also effectively eliminated patient AML cells in vivo [36]. Anti-human NKG2A mAb have also been explored as a means of selectively differentiating and optimizing NK cells [37]. $\mathrm{NKG}_{2} \mathrm{~A}^{+}$is expressed on NK cells whereas its inactivating ligand, HLA-E, is expressed on normal and AML cells. In preclinical studies, immunodeficient mice infused with primary AML and $\mathrm{NKG}_{2} \mathrm{~A}^{+}$nonalloreactive $\mathrm{NK}$ cells eventually showed tumor engraftment. By contrast, mice receiving NK cells pre-treated with anti-NKG2A mAb showed remarkable resistance to engraftment and survived up to 100 days without signs of tumor localization or neoplastic infiltration. In other experiments, mice were transplanted with normal CD34 $4^{+}$hematopoietic cells followed by subsequent inoculation with AML cells and variable doses of $\mathrm{mAb}$. Although low-dose anti-NKG2A mAb therapy did not attenuate leukemia progression, mice receiving 200-300 $\mu \mathrm{g}$ of $\mathrm{mAb}$ survived with total ablation of AML cells in marrow and spleen. Taken together, these results suggest that $\mathrm{CD} 34^{+}$hematopoietic progenitors have the potential to successfully differentiate into endogenous $\mathrm{NKG}_{2} \mathrm{~A}^{+} \mathrm{NK}$ cells capable of lethally eradicating leukemia cells following in vivo $\mathrm{mAb}$ stimulation.

\section{CART-expressing NK cells}

NK cells have also been re-engineered using CAR technologies with the goal of enhancing their affinity and cytotoxicity against AML cells without inducing GVHD (Figure 2). Moreover, given their differing spectrum of cytokine production, CAR-transduced NK cells could also complement the antileukemic activity of CART therapies. To date, however, the empiric data supporting this approach remain significantly limited [38]. In one study, $\alpha$-retroviral vectors were utilized to deliver anti-CD123 CAR constructs into the human NK cell line, NK 92, as an efficient platform for CAR-based transfection [39]. The cytotoxic capacity of these re-engineered NK 92 cells against the $\mathrm{CD} 123^{+}$-specific AML line KG1a was markedly enhanced. Rafiq et al. similarly utilized retroviral constructs to transduce NK 92 cells with CAR constructs containing anti-CD33 domain [40]. Transduced CD33 CAR NK cells exhibited significant in vitro killing of AML cells and primary blasts. Leukemia-engrafted mice receiving anti-CD33 transduced NK 92 cell infusions also survived significantly longer.

\section{Other adoptive cellular therapies}

Although CART and NK cells have received the lion's share of interest as adoptive cellular immunotherapy for AML, several other candidate immune cell populations have also been studied over recent years. These include non-specific immune effectors such as CIK cells and $\gamma \delta$ T lymphocytes [41].

\section{Cytokine-induced killer cells}

CIKs have a heterogeneous phenotype with simultaneous co-expression of both T-cell (CD3) and NK (CD56) cell markers. As such, they are capable of mediating cytotoxicity against cancer cells in both $\mathrm{MCH}$-restricted and non-MHC-restricted manners. Preclinical studies have revealed CIKs to exert potent antitumor activity in vitro and in vivo. Moreover, multiple Phase I clinical trials of adoptive CIK cell infusions has established the feasibility and safety of this approach in AML patients [42,43]. In fact, the benefits of autologous or allogeneic CIK cell infusion have previously been demonstrated in 206 patients with hematologic malignancies. Impressively, approximately $40 \%$ of patients attained disease control. Specific studies highlighting the clinical application of CIK infusion for AML include a report by Wang et al. describing a patient with RR-AML who experienced a dramatic reduction in leukemic burden after four CIK infusions given over 4 months [44]. A more recent study evaluated the safety and feasibility of IL-15-activated CIK cells as a means of preventing relapse in high-risk leukemia [45]. Four patients with detectable molecular relapse received between two and nine cycles of CIK infusions from either matched sibling or unrelated donors. All four subsequently achieved complete molecular remission (MR) lasting between 4.6 months and 1.1 years. To further enhance antileukemic activity, CIK cells possessing spontaneous anti-tumor activities have also been transduced to express an anti-CD123 CAR via an SFG retroviral vector. These cells display 


\begin{tabular}{|c|c|c|c|c|c|c|}
\hline Study & $\begin{array}{l}\text { Antigen } \\
\text { target }\end{array}$ & Therapy & In vitro effects & In vivo effects & Stage of development & Ref \\
\hline Liu et al. & PD-1 & Nivolumab & $\begin{array}{l}\text { Sequencing of TCR-a and TCR-b } \\
\text { chains from three AML patients } \\
\text { revealed select anti-AML } \\
\text { clonotypes become drastically } \\
\text { enriched }\end{array}$ & Not available & Phase II & [51] \\
\hline Albring et al. & PD-1 & Nivolumab & Not available & $\begin{array}{l}\text { Two out of three previously } \\
\text { relapsed patients in CR or } \\
\text { molecular disease stabilization } \\
\text { after treatment }\end{array}$ & $\begin{array}{l}\text { Case series administered } \\
\text { under compassionate use }\end{array}$ & [52] \\
\hline Davids et al. & CTLA-4 & Ipilimumab & $\begin{array}{l}\text { Regulatory T cell: conventional } \\
\text { T-cell ratio decreased during } \\
\text { treatment among responders }\end{array}$ & $\begin{array}{l}\text { Five out of } 12 \text { achieved CR, } 67 \% \\
\text { overall survival rate at } 6 \text { months }\end{array}$ & Phase I & [56] \\
\hline
\end{tabular}

non-HLA-restricted cytotoxicity with minimal alloreactivity. Anti-CD123 CIK CART cells exhibited potent in vitro cell killing of CD123+ THP-1 AML cells and primary blasts [46]. A Phase II trial is investigating whether administration of CIK cells with recombinant IL-15 (ALT-803) 7 days after alloSCT can control MRD and prevent AML relapse (NCT02782546).

\section{$\gamma \delta$ T lymphocytes}

Human $\gamma \delta$ T lymphocytes are a unique subset of peripheral blood immune cells defined by their T-cell receptor expression. These cells are capable of infiltrating multiple tumor sites, producing cytokines and mediating potent HLA-unrestricted cytotoxic activity against malignant cells, including AML cells [47,48]. Autologous $\gamma \delta \mathrm{T}$ lymphocyte-based cell therapy is made possible via large scale ex vivo expansion of these cells from patient peripheral blood samples co-cultured with IL-2 and synthetic molecular drugs (BrHPP, zoledronate). A recent Phase I/II trial evaluated 21 cancer patients who received a total of 58 treatments of infused autologous $\gamma \delta \mathrm{T}$ lymphocytes. This study confirmed the tolerability and safety of these cells and also demonstrated significant in vivo activation and expansion of $\gamma \delta \mathrm{T}$ lymphocytes in all evaluable patients. Of note, two patients with AML had evidence of clinical activity defined as partial remissions [49].

\section{Checkpoint inhibitors \\ Anti-PD-1/PD-L1}

PD-1 is an inhibitory receptor of the B7/CD28 superfamily present on T-cells, with a significant role in inhibiting T-cell activation and effector function in the inflammatory milieu through its binding with the ligand PD-L1. PD-L1 is typically present on the surface of antigen presenting cells, as well as tumor cells. Engagement of PD-1 with PD-L1 functions to suppress T-cell activation and effector functions. This PD-1/PD-L1 interaction has also been shown to play a role in the immune escape of leukemia cells and contributes to their long-term persistence. A correlation between increased PD-L1 expression and AML patient relapse has previously been reported [50].

Inhibiting the PD-1/PD-L1 interaction aims to reinstate T-cell mediated antitumor immunity. Clinical studies of the effects of anti-PD-1/PD-L1 mAbs in myeloid malignancies are ongoing. For instance, recruitment is underway for a study evaluating the potential for nivolumab to eradicate MRD and preventing AML relapse in patients with MRD-positive disease following upfront chemotherapy (NCT02275533). This randomized Phase II crossover study aims to assess progression-free survival for up to 2 years after initial treatment, as well as nonrelapse mortality and OS. Patients will receive nivolumab every 2 weeks for 46 courses as long as treatment is well tolerated with no signs of disease progression. Preliminary data from deep sequencing of T cell receptors (TCR-a and TCR-b chains) of $\mathrm{T}$ cells from three AML patients enrolled in the study have revealed that certain anti-AML clones may become drastically enriched in response to nivolumab treatment [51]. In a similar Phase II trial, AML patients in remission but at high risk for relapse (NCT02532231) will receive nivolumab $(3 \mathrm{mg} / \mathrm{kg})$ every second week for a total of six cycles (each cycle defined as 1 month) with possible extension of treatment for those with good tolerance. Dosing after cycle 6 can be modified to a monthly schedule up to 12 months from treatment onset, then every 3 months until progression (Table 3). 
Contemporary approaches to AML therapy with curative intent have included various iterations of stem cell transplantation and/or donor lymphocyte infusions, focusing on their intrinsic capacity to elicit durable GVL effects. The variable success with these approaches may in part be due to immune escape mechanisms mediated by PD-1 upregulation on leukemia cells which compromise GVL. Albring et al. recently reported multiple case studies involving nivolumab administration in patients with relapsed AML after allogeneic SCT and failing standard therapy [52]. The first patient, a 61-year-old man, progressed to overt AML approximately 8 months after alloSCT and received a single dose of nivolumab $(100 \mathrm{mg})$. The patient subsequently developed marked pancytopenia and a single episode of steroid-responsive skin GVHD a few weeks after administration. The patient's marrow blast count declined to $5 \%$ within 50 days of nivolumab injection. He remains in CR with good performance status over 10 months after treatment. A second patient, a 44-year-old woman received five low-dose infusions of nivolumab $(0.3-1.0 \mathrm{mg} / \mathrm{kg})$ with resultant molecular disease stabilization for 6 months. A third patient, a 50-year-old man, received two injections of nivolumab $(100 \mathrm{mg})$ on days 157 and 171 after alloSCT but failed to show a demonstrable response. Interestingly, patients 2 and 3 both had appreciable increases in CTLA-4-expressing T cells following nivolumab.

\section{Anti-CTLA-4}

CTLA-4 is an often studied co-inhibitory receptor expressed predominantly on T cells [53]. It is homologous to CD28 and shares identical ligands (CD80 and CD86). However, CTLA-4 binds these ligands with greater affinity than CD28 and results in inhibition, rather than stimulation, of T-cell activation. Preclinical studies with murine models have shown that CTLA- 4 ligand expression is upregulated in longstanding AML cell lines similar to upregulation of PD-L1. Such cells are generally more resistant to lysis by cytotoxic T cells. Blockade of the CTLA- 4 and PD- 1 axis can, in turn, increase cytotoxic T cell-mediated lysis against persistent leukemia cells that mimic MRD [54]. Other studies have further demonstrated that CTLA-4 blockade can significantly influence T-cell response to AML. Checkpoint inhibition has been shown to increase the frequency, number, cytotoxic activity and IFN- $\gamma$ production of AML-specific T cells as compared with cells cultured without CTLA-4-directed antibodies [55].

A Phase I/Ib trial of ipilimumab in patients with relapsed hematologic malignancy following alloSCT has enrolled 28 patients, including 12 with relapsed AML [56]. Patients received intravenous (iv.) ipilimumab induction every 3 weeks for four cycles, followed by maintenance dosing in 12-week increments for up to 1 year. Five of 12 AML patients (42\%) achieved CR, including three patients with leukemia cutis. Across all patients, $67 \%$ of patients survived 6 months, with four patients showing durable response for $>1$ year. Among responders, the $T_{\text {reg }} / T_{\text {con }}$ cell ratios decreased during treatment, suggesting an increase in GVL activity. Responses were also correlated with in situ infiltration of $\mathrm{CD} 8^{+}$cells and expansion of effector T-cell populations in blood. Ipilimumab has also undergone clinical testing for R/R high-risk MDS and AML with MRD (NCT01757639). Patients receive ipilimumab every 3 weeks for up to four courses if tolerated without disease progression. Subsequently, maintenance therapy can be conducted 12 weeks after last induction dose, with repeated doses given 12 weeks apart for four courses. Goals of this trial include determining DLTs and the maximally tolerated dose of ipilimumab for AML patients who completed induction but have no further plans for intensive chemotherapy. In addition, it will evaluate the immunologic profiles associated with ipilimumab response and provide preliminary data on efficacy (CR, partial response or hematologic improvement) in myeloid malignancies.

\section{TIM-3}

TIM-3 is an inducible, inhibitory receptor expressed on a multitude of immune effectors, including macrophages, DCs, T-regulatory cells, Th1 and $\mathrm{CD}^{+}$cells. Hematopoietic progenitors generally do not express TIM-3, and mature normal leukocytes show an inverse pattern of expression. In contrast, AML cells have high expression levels of both TIM-3 receptors and Kit receptors, thereby substantially increasing their growth and proliferation potential [57]. Recent flow cytometry and quantitative RT-PCR analysis has also revealed that expression of leukemic stem cell markers, including TIM-3, is strongly correlated with poor prognosis among AML patients [58]. Gal-9, a primary ligand for TIM-3, has been shown to induce apoptosis in T-cells and impair cytokine function in NK cells. Recent work by Goncalves Silva et al. reported that Gal-9 is expressed and secreted by myeloid leukemia cells in a process that is upregulated by pro-inflammatory stimulation [59]. Gal-9 release appears to be dependent on TIM-3 as TIM-3 knockdown mice have significantly lower levels of Gal-9 relative to wild-type cells.

Blockade of TIM3 pathway has been shown to increase proliferation of effectors and cytotoxicity of T-cells [60]. As such, blockade of this axis may serve as a viable candidate for future immunomodulatory agents against AML. 


\begin{tabular}{|c|c|c|c|c|c|c|}
\hline Study & Antigen target & Construct & In vitro effects & In vivo effects & $\begin{array}{l}\text { Stage of } \\
\text { development }\end{array}$ & Ref. \\
\hline Bigalke et al. & WT-1/PRAME & $\begin{array}{l}\text { DCs produced with TLR } \\
7 / 8 \text { ligand R848 }\end{array}$ & $\begin{array}{l}\text { Variable CD4/CD8 response } \\
\text { against PRAME and WT-1 }\end{array}$ & $\begin{array}{l}\text { DC vaccination induced or } \\
\text { supported specific T-cell } \\
\text { response in four out of five } \\
\text { patients. Three are in CR after } \\
21,25 \text { and } 33 \text { months, } \\
\text { respectively }\end{array}$ & $\begin{array}{l}\text { Case series, } \\
\text { administered under } \\
\text { compassionate use }\end{array}$ & [52] \\
\hline Anguille et al. & WT-1 & $\begin{array}{l}\text { DCs with either WT-1 } \\
\text { mRNA, WT-1-DC-LAMP, } \\
\text { WT-1-DC-LAMP-OPT }\end{array}$ & Unavailable & $\begin{array}{l}30 \% \text { of patients with } \\
\text { molecular response, } 13 \% \text { with } \\
\text { stable disease }\end{array}$ & Phase II & [63] \\
\hline Kobayashi et al. & WT-1 & $\begin{array}{l}\text { OCV-501 (WT-1 derivative } \\
\text { peptide) }\end{array}$ & $\begin{array}{l}\text { Dose-dependent } \\
\text { OCV-501-specific Th1 } \\
\text { response and helper activity; } \\
\text { significant cytolytic activity } \\
\text { against B-LCL cells }\end{array}$ & $\begin{array}{l}\text { Five out of nine patients with } \\
\text { reduction in WT-1 mRNA } \\
\text { levels; no documented relapse }\end{array}$ & Phase I & [64] \\
\hline Maslak et al. & WT-1 & $\begin{array}{l}\text { SLS-001 (WT-1 analog } \\
\text { peptide) }\end{array}$ & $\begin{array}{l}\text { Nine out of } 14 \text { patients } \\
\text { showed immunologic } \\
\text { response on correlative assay }\end{array}$ & $\begin{array}{l}\text { Median leukemia-free } \\
\text { survival } 23.5 \text { months; overall } \\
\text { survival } 45.5 \text { months }\end{array}$ & Phase II & [65] \\
\hline Brayer et al. & WT-1 & $\begin{array}{l}\text { Polyvalent WT-1 directed } \\
\text { peptide }\end{array}$ & $\begin{array}{l}\text { No statistically significant } \\
\text { WT-1-specific immune } \\
\text { response }\end{array}$ & $\begin{array}{l}\text { Four out of } 14 \text { patients with } \\
\text { sustained response longer } \\
\text { than first remission; two out } \\
\text { of } 14 \text { with relapse-free } \\
\text { survival }>12 \text { months }\end{array}$ & Phase I & [66] \\
\hline Qazilbash et al. & $\begin{array}{l}\text { PR-1 } \\
\text { (HLA-A2-restricted } \\
\text { peptide derived } \\
\text { from neutrophil } \\
\text { elastase + PRTN3) }\end{array}$ & PR-1 peptide vaccine & $\begin{array}{l}53 \% \text { of patients showed } \\
\text { immune response with }>2 \times \\
\text { increase in PR-1-specific CTLs }\end{array}$ & $\begin{array}{l}12 \text { out of } 53 \text { patients with } \\
\text { clinical response, primarily in } \\
\text { those with low disease } \\
\text { burden }\end{array}$ & Phase I/II & [67] \\
\hline Khoury et al. & hTERT & $\begin{array}{l}\text { DCs transfected with } \\
\text { hTERT and LAMP }\end{array}$ & Unavailable & $\begin{array}{l}58 \% \text { ( } 11 \text { out of } 19) \text { patients } \\
\text { free of disease at time of } \\
\text { long-term follow-up }\end{array}$ & Phase II & [69] \\
\hline Rosenblatt et al. & Not available & DC/AML fusion cells & $\begin{array}{l}4.9 \times \text { increase in } \mathrm{CD}^{+} \text {cells } \\
\text { expressing IFN- } \gamma \text { in response } \\
\text { to leukemia cell lysate }\end{array}$ & $\begin{array}{l}12 \text { out of } 16 \text { patients remain } \\
\text { in remission } \\
\text { (median: } 45 \text { months) }\end{array}$ & Phase I & [70] \\
\hline Chevallier et al. & Not available & $\begin{array}{l}\text { DC derived from } \\
\text { autologous apoptotic } \\
\text { leukemic cells }\end{array}$ & Unavailable & $\begin{array}{l}\text { Duration of response from CR } \\
\text { ranged from } 4 \text { to } 12 \text { months } \\
\text { among five patients }\end{array}$ & Phase I/II & [71] \\
\hline Lichtenegger et al. & $\begin{array}{l}\text { WT- } \\
\text { 1/PRAME/CMVpp65 }\end{array}$ & $\begin{array}{l}\text { DCs produced with TLR } \\
7 / 8 \text { ligand }\end{array}$ & $\begin{array}{l}\text { DC express PD-L1 and } \\
\text { HLA-DR; DC-activated T-cells } \\
\text { upregulated PD-1 and LAG-3; } \\
\text { blockade of PD1/LAG-3 } \\
\text { enhanced IFN- } \gamma \text { secretion and } \\
\text { T-cell proliferation }\end{array}$ & $\begin{array}{l}\text { Seven out of ten patients } \\
\text { alive; five in CR with an } \\
\text { observation period up to } \\
840 \text { days }\end{array}$ & Phase I/II & [72] \\
\hline
\end{tabular}

Darwish reported on the in vitro inhibitory effect of anti-TIM-3 on human AML cells by interfering with cell proliferation [58]. Anti-human TIM-3 IgG antibody treatment has also been shown to effectively eradicate AML leukemic stem cells in vivo in xenograft models while preserving normal hematopoiesis [61].

\section{Vaccine therapy}

DC-based immunotherapy involves utilizing antigen-loaded DCs to induce a Th1 response which, in turn, generates cytotoxic $\mathrm{T}$ cells that target and lyse antigen-expressing tumor cells. AML cells express a multitude of leukemia-associated antigens, including WT-1, PRTN3, preferentially expressed antigen in melanoma (PRAME) and (hTERT (Table 4). In addition, peptide-based vaccine approaches have also been utilized to generating an antigen-specific IRs.

\section{WT-1 vaccines}

DC vaccines targeting WT-1 and PRAME have previously been investigated in AML patients [62]. Monocyte derivatives were collected from four patients via apheresis, matured with TLR7/8 ligand R848 and prepared to separately express mRNA encoding both target antigens. DC vaccines were then administered intradermally on 
a weekly basis for 4 weeks and subsequently on a monthly basis if well tolerated. One patient showed strong, persistent $\mathrm{CD}^{+}$responses to PRAME, as well as an unexpected increase in hTERT reactivity, raising the possibility of epitope spreading. This patient continued to receive monthly DC inoculations with low WT-1 PCR signaling in marrow and no detectable signal in blood for $>60$ weeks. A second patient showed WT-1-specific IRs through 37 weeks. After developing Bell's palsy and undergoing cortisone therapy, this patient's peripheral blasts increased with an accompanying increase in marrow WT-1 signaling. More recently, a Phase II study evaluated the capability of vaccination with DCs electrocorporated with WT-1 mRNA as postremission therapy for 30 AML patients at very high risk for relapse [63]. Three WT-1 constructs were utilized to generate mRNA by in vitro transcription: construct 1 (WT-1) encoded full-length WT-1, construct 2 (WT-1-DC-LAMP) incorporated a Sig-DC-LAMP MHCII skewing signal with deletion of the WT-1 nuclear localization signal, and construct 3 (WT-1-DC-LAMPOPT was a codon-optimized version of construct 2). The vaccines were administered intradermally following achievement of morphologic response after chemotherapy in 27 patients with CR and three with PR. Overall, the clinical response rate was $43 \%$, with $30 \%$ of patients achieving MR (defined as normalization of WT-1 transcript levels), and $13 \%$ achieving SD. When assessing the constructs individually, vaccination with construct 1 resulted in seven patients achieving MR, one with SD and eight with no response, yielding a median OS of 23.3 months and 5 -year OS of $31 \%$. Out of the six patients who received construct 2, two had MR, one had SD and two had no response with one undefined response. The median OS was 69.2 months with a 5-year OS of 50\%. Last, construct 3 was provided to eight patients, two of which had SD and six with no response. Despite this, the median OS was found to be 50.8 months with 50\% 5-year OS. Therapy appeared nontoxic with no adverse effects reported.

Attempts have been made to further enhance the antigenic potential of WT-1. OCV-501 is a helper peptide derived from the WT-1 protein, which has been shown to induce specific Th1 responses and helper activity in peripheral blood from healthy donors [64]. It has been proposed that OCV-501 could serve as a peptide vaccine, activating both direct and indirect anti-leukemic immunity, including activity of WT-1-specific cytotoxic $\mathrm{T}$ cells. In a recent open-label, multicenter trial, OCV-501 vaccination was administered to elderly AML patients in morphologic CR following standard consolidation with WT-1 mRNA-positive disease. No DLTs were observed. Although no patients had demonstrable relapse, five of nine patients showed reductions in WT-1 mRNA levels. Delayed type hypersensitivity testing showed a measurable in all patients. Multiple investigators have evaluated vaccine iterations integrating WT-1 motifs. For example, a multivalent WT-1 peptide vaccine, SLS-001, comprised of two native and two heteroclitic WT-1 peptides, has been developed [65]. In a Phase II study for adults with AML in morphologic CR with PCR measurable WT-1 transcript levels, vaccination was generally well tolerated with only minor injection site reaction and skin induration. Nine of 14 evaluable patients showed immunologic response on correlative assays. Median disease-free survival was 23.5 months, with OS of 45.5 months. Patients without detectable IRs had shorter disease-free survival and OS, suggesting a potential benefit to vaccination. Recently, the safety, tolerability and immunogenicity of a polyvalent WT-1 peptide vaccine has been evaluated in AML patients in first or second CR and high-risk MDS [66]. This vaccine was designed to elicit native WT-1-specific IRs by incorporating a combination of class I and class II peptide epitopes. A total of six vaccinations were given on a biweekly schedule, followed by six additional vaccinations once a month for a total of 12 inoculations. Sargramostim was given to help maximize immunogenic potential. Among 16 patients enrolled, ten completed the initial six vaccinations, and six patients received additional monthly vaccinations. With the exception of one instance of grade 3/4 neutropenia and several instances of local injection site skin induration and erythema, therapy was well tolerated. Among 14 AML patients, the calculated mean time to recurrence was 244 days (range: 30-445) while mean OS from time of remission was 608 days (range: 201-1071 days). At the time of publication, all patients had evidence of disease progression with only three patients still alive. Notably, four out of 14 (28\%) patients showed sustained responses with durations equal to or exceeding the duration of their first remission. In addition, two patients had RFS lasting $>1$ year. Unfortunately there was no evidence that vaccination caused WT-1-specific IRs, although several patients with clinical improvement also had detectable WT-1 reactivity.

\section{PR1 vaccines}

PR1 is a 9-amino acid long HLA-A2 restricted peptide derived from neutrophil elastase and PRTN3, which is frequently expressed on myeloid leukemia cells and readily detected by $\mathrm{CD} 8^{+}$cells when bound to HLA-A2. In a Phase I/II trial, patients with myeloid malignancies expressing HLA-A2 ${ }^{+}$received three to six PR1 peptide vaccinations subcutaneously every 3 weeks with GM-CSF. Over $50 \%$ of patients $(\mathrm{n}=66)$ demonstrated IRs with more than twofold increase in PR-1-specific CTLs. Totally, 12 of 53 patients with detectable disease had clinical 
responses (23\%). Most patients (11 of 12$)$ had low disease burden ( $<10 \%$ marrow blasts). Importantly, IRs after vaccination were associated with lower numbers of marrow blasts $(<5 \%, \mathrm{p}=0.01)[67]$.

\section{hTERT vaccine}

Telomerase is a ribonucleoprotein, which synthesizes telomeric DNA and plays a pivotal role in prolonging the lifespan of malignant cells [68]. This protein is highly upregulated in patients with AML, particularly those with poor risk cytogenetics. Khoury et al. evaluated a DC vaccine, consisting of mature DCs transfected with mRNAencoding telomerase (hTERT) and LAMP, in AML patients [69]. Twenty-one patients in morphologic remission after prior therapy received a median number of 19 vaccinations with hTERT-DC (range: 3-32). Almost 100\% of patients received the full complement of six primary vaccinations and $62 \%$ received both primary and boost vaccinations. Therapy was well tolerated with fatigue and headache in $24 \%$. Six patients (29\%) experienced adverse events including idiopathic thrombocytopenic purpura, perforated appendicitis and small intestinal obstruction. Totally, 11 of 19 patients (58\%) remained in CR with a median follow-up of 52 months (range: 13-59).

\section{Vaccines targeting multiple leukemia antigens}

An autologous whole-cell vaccine utilizing AML patient derived blasts fused with ex vivo generated DCs (DC/AML) has recently been developed to express a larger spectrum of leukemia antigens simultaneously and therefore induce a more potent polyclonal IR [70]. In an early clinical trial, $21 \mathrm{AML}$ patients in CR underwent leukopheresis for DC generation and vaccine preparation. Patient-derived mononuclear cells were cultured with GM-CSF and IL-4 for a week and exposed to TNF- $\alpha$ to generate mature DCs. Fusion cells were created by co-culturing DCs with AML cells, with a mean fusion efficiency of 42\%. Inoculation with DC/AML fusion cells was begun within 12 weeks of count recovery after induction chemotherapy. To date, 16 patients have undergone at least two monthly vaccinations with $5 \times 10^{6}$ cells. Vaccination had been generally well tolerated with low-grade pruritus, arthralgias, myalgias and cytopenias. Totally, 12 of 16 patients (75\%) remained in CR with a median follow-up of 45 months, and vaccination resulted in a mean 4.9-fold increase in $\mathrm{CD}^{+}$cells expressing IFN- $\gamma$ in response to ex vivo leukemia cell lysates.

In another approach, Chevallier $e t$ al. utilized autologous apoptotic leukemic cells as a source of tumor antigen vaccination in a Phase I/II study for older patients (median age 74 years) with overt AML disease (median marrow blasts of 63\%) [71]. Patients in CR after nonintensive chemotherapy underwent apheresis and received five vaccine doses consisting of pulsed DCs administered subcutaneously and intradermally. No adverse events were documented. Duration of response from initial CR ranged from 4 to 12 months and from first vaccination between 1.8 and 9 months. At day 55, three patients had negative MRD status by flow cytometry.

Autologous next-generation DC vaccination has also been investigated as postremission therapy for AML patients with nonfavorable risk profiles [72]. As part of a proof-of-concept trial, monocyte-derived next-generation DCs loaded with mRNA encoding the leukemia-associated antigens WT-1 and PRAME as well as CMVpp65 as a surrogate antigen were generated and explored in an expanded dose cohort of 13 patients. Eleven had DCs generated from leukopheresis with high co-stimulatory molecule expression, IL-12 secretion and antigen presentation. In nine evaluable patients, there were no grade 3 or 4 toxicities observed, although delayed-type hypersensitivity responses at vaccination sites were noted in all patients. Peripheral blood samples demonstrated vaccination-specific T-cell responses on multimer staining and ELISPOT analysis, suggesting an active vaccination-induced IR. At the time of publication, seven of ten patients were alive, five were in CR with an observation period of up to 840 days.

\section{Future perspective}

Immunotherapy remains a highly promising approach for the treatment of acute myeloid leukemia, particularly patients otherwise ineligible for alloSCT and in MRD states. Despite the tremendous potential of this modality, numerous clinical challenges remain. Barriers to the successful implementation of novel immunotherapeutic approaches include: heterogeneous antigen expression on diverse AML cell populations, the need for generation of potent and sustained IRs and the risk of possible off-target toxicities to normal myeloid progenitor and hematopoietic stem cells as well as life-threatening CRS and neurological events. Other challenges include high tumor burden, immune cell exhaustion and clonal evolution of tumor cells over time. To date, much emphasis has been placed on determining the optimal antigenic targets and the timing of immunotherapy in relation to chemotherapy and alloSCT. Future efforts are needed to delineate how best to integrate immunotherapeutic approaches into curative treatment regimens for acute myeloid leukemia. 


\section{Executive summary}

- Novel immunotherapeutic approaches for acute myeloid leukemia (AML):

1. CART therapy.

2. Natural killer cell therapy.

3. Other adoptive cellular approaches.

4. Checkpoint inhibition.

5. Vaccines.

- Patient subsets most likely to benefit from immunotherapy:

1. Older patients ineligible for stem cell transplant.

2. Relapsed/refractory AML patients after prior hematopoietic stem cell transplant.

3. Patients in complete recovery at high risk for relapse (minimal residual disease positive).

- Obstacles to successful implementation of immunotherapy:

1. Heterogeneous tumor antigen expression in diverse AML subtypes.

2. Off-target toxicities (myelosuppression).

3. Immune cell exhaustion.

4. Life-threatening complications of potent immune activation.

Financial \& competing interests disclosure

This work was supported by Roswell Park Cancer Institute and National Cancer Institute (NCI) grant number P30CA016056. ES Wang is also supported by the RPCI Alliance Foundation (Jacquie Hirsch Leukemia Research Fund). The authors have no other relevant affiliations or financial involvement with any organization or entity with a financial interest in or financial conflict with the subject matter or materials discussed in the manuscript apart from those disclosed.

No writing assistance was utilized in the production of this manuscript.

\section{References}

Papers of special note have been highlighted as: • of interest; $\bullet \bullet$ of considerable interest

1 Wang ES. Treating acute myeloid leukemia in older adults. Hematol. Am. Soc. Hematol. Educ. Program (1), 14-20 (2014).

2 Khalil DN, Smith EL, Brentjens RJ, Wolchok JD. The future of cancer treatment: immunomodulation, CARs and combination immunotherapy. Nat. Rev. Clin. Oncol. 13(6), 273-290 (2016).

3 Fan M, Li M, Gao L et al. Chimeric antigen receptors for adoptive T cell therapy in acute myeloid leukemia. J. Hematol. Oncol. 10(1), 151 (2017).

4 Lynn RC, Poussin M, Kalota A et al. Targeting of folate receptor beta on acute myeloid leukemia blasts with chimeric antigen receptor-expressing T cells. Blood 125(22), 3466-3476 (2015).

5 Lu H, Zhou Q, Deshmukh V et al. Targeting human C-type lectin-like molecule-1 (CLL1) with a bispecific antibody for acute myeloid leukemia immunotherapy. Angew. Chem. Int. Ed. Engl. 53(37), 9841-9845 (2014).

6 Kenderian S, Ruella M, Shestova $\mathrm{O}$ et al. Leukemia stem cells are characterized by CLEC12A expression and chemotherapy refractoriness that can be overcome by targeting with chimeric antigen receptor T cells. Presented at: Annual Meeting of the American Society of Hematology. CA, USA, 3-6 December 2016.

7 Chien C, Sauter CT, Ishii K et al. Preclinical development of FLT3-redirected chimeric antigen receptor T cell immunotherapy for acute myeloid leukemia. Am. Soc. Hematol. 128(220), 1072 (2016).

8 Ploch P, Khan S, Bhatti A, Krebs L, Theobald M, Hartwig UF. Exploring chimeric natural killer receptor NKP30 expressing human T lymphocytes for adoptive immunotherapy to acute leukemia. Presented at: 21st Congress of the European Hematology Association. Copenhagen, Denmark, 9-12 June 2016.

9 Goltz D, Gevensleben H, Grunen S et al. PD-L1 (CD274) promoter methylation predicts survival in patients with acute myeloid leukemia. Leukemia 31(3), 738-743 (2017).

10 Dinndorf PA, Andrews RG, Benjamin D, Ridgway D, Wolff L, Bernstein ID. Expression of normal myeloid-associated antigens by acute leukemia cells. Blood 67(4), 1048-1053 (1986).

11 Kenderian SS, Ruella M, Shestova $\mathrm{O}$ et al. CD33-specific chimeric antigen receptor $\mathrm{T}$ cells exhibit potent preclinical activity against human acute myeloid leukemia. Leukemia 29(8), 1637-1647 (2015).

12 Rafiq S, Purdon TJ, Schultz LM, Brentjens RJ. CD33-directed chimeric antigen receptor (CAR) T cells for the treatment of acute myeloid leukemia (AML). Presented at: Annual Meeting of the American Society of Hematology. CA, USA, 3-6 December 2016.

13 O'Hear C, Heiber JF, Schubert I, Fey G, Geiger TL. Anti-CD33 chimeric antigen receptor targeting of acute myeloid leukemia. Haematologica 100(3), 336-344 (2015). 
14 Minagawa $\mathrm{K}$, Jamil MO, Al-Obaidi $\mathrm{M}$ et al. In vitro pre-clinical validation of suicide gene modified anti-CD33 redirected chimeric antigen receptor T-cells for acute myeloid leukemia. PLoS ONE 11(12), e0166891 (2016).

- Reviews the most advanced CART construct for acute myeloid leukemia (AML) with potential to mediate antileukemic effects with tolerable clinical activity.

15 Wang QS, Wang Y, Lv HY et al. Treatment of CD33-directed chimeric antigen receptor-modified T cells in one patient with relapsed and refractory acute myeloid leukemia. Mol. Ther. 23(1), 184-191 (2015).

16 ClinicalTrials.gov. https://clinicaltrials.gov/ct2/home

17 Testa U, Riccioni R, Diverio D, Rossini A, Lo Coco F, Peschle C. Interleukin-3 receptor in acute leukemia. Leukemia 18(2), 219-226 (2004).

18 Mardiros A, Dos Santos C, McDonald T et al. T cells expressing CD123-specific chimeric antigen receptors exhibit specific cytolytic effector functions and antitumor effects against human acute myeloid leukemia. Blood 122(18), 3138-3148 (2013).

19 Gill S, Tasian SK, Ruella M et al. Preclinical targeting of human acute myeloid leukemia and myeloablation using chimeric antigen receptor-modified T cells. Blood 123(15), 2343-2354 (2014).

20 OncLive. www.onclive.com/web-exclusives/fda-lifts-holds-on-offtheshelf-cart-trials

21 Nikiforow S, Werner L, Murad J et al. Safety data from a first-in-human Phase I trial of NKG2D chimeric antigen receptor-T cells in AML/MDS and multiple myeloma. Presented at: Annual Meeting of the American Society of Hematology. CA, USA, 3-6 December 2016.

22 Peinert S, Prince HM, Guru PM et al. Gene-modified T cells as immunotherapy for multiple myeloma and acute myeloid leukemia expressing the Lewis Y antigen. Gene Ther. 17(5), 678-686 (2010).

23 Ritchie DS, Neeson PJ, Khot A et al. Persistence and efficacy of second generation CAR T cell against the LeY antigen in acute myeloid leukemia. Mol. Ther. 21(11), 2122-2129 (2013).

24 Smyth MJ, Cretney E, Takeda K et al. Tumor necrosis factor-related apoptosis-inducing ligand (TRAIL) contributes to interferon gamma-dependent natural killer cell protection from tumor metastasis. J. Exp. Med. 193(6), 661-670 (2001).

25 Kottaridis PD, North J, Tsirogianni M et al. Two-stage priming of allogeneic natural killer cells for the treatment of patients with acute myeloid leukemia: a Phase I trial. PLoS ONE 10(6), e0123416 (2015).

26 Ruggeri L, Capanni M, Urbani E et al. Effectiveness of donor natural killer cell alloreactivity in mismatched hematopoietic transplants. Science 295(5562), 2097-2100 (2002).

- Demonstrates the antitumor potential of natural killer cells in the setting of allogeneic stem cell transplants.

27 Lee DA, Denman CJ, Rondon G et al. Haploidentical natural killer cells infused before allogeneic stem cell transplantation for myeloid malignancies: a Phase I trial. Biol. Blood Marrow Transplant. 22(7), 1290-1298 (2016).

28 Shaffer BC, Le Luduec JB, Forlenza C et al. Phase II study of haploidentical natural killer cell infusion for treatment of relapsed or persistent myeloid malignancies following allogeneic hematopoietic cell transplantation. Biol. Blood Marrow Transplant. 22(4), 705-709 (2016).

- Reports the tolerability and efficacy of this therapy in the largest set of AML patients $(n=8)$.

29 Curti A, Ruggeri L, Parisi S et al. Larger size of donor alloreactive NK cell repertoire correlates with better response to NK cell immunotherapy in elderly acute myeloid leukemia patients. Clin. Cancer Res. 22(8), 1914-1921 (2016).

30 Björklund AT, Clancy T, Goodridge JP et al. Naive donor NK cell repertoires associated with less leukemia relapse after allogeneic hematopoietic stem cell transplantation. J. Immunol. 196(3), 1400-1411 (2016).

31 Berrien-Elliott MM, Wagner JA, Fehniger TA. Human cytokine-induced memory-like natural killer cells. J. Innate Immun. 7(6), 563-571 (2015).

32 Romee R, Rosario M, Berrien-Elliott MM et al. Cytokine-induced memory-like natural killer cells exhibit enhanced responses against myeloid leukemia. Sci. Transl. Med. 8(357), 357ra123 (2016).

- Describes the potential of a novel adoptive cellular therapy for AML.

33 Dolstra H, Roeven MWH, Spanholtz J et al. A Phase I study of allogeneic natural killer cell therapy generated from cord blood hematopoietic stem and progenitor cells in elderly acute myeloid leukemia patients. Presented at: Annual Meeting of the American Society of Hematology. FL, USA, 5-8 December 2015.

34 Feniger T, Stuart R, Cooley S, Salhotra A. CNDO-109-activated allogeneic natural killer cells in patients with high risk acute myeloid leukemia in first complete remission (CR1): a Phase I study. Presented at: Innate Killer Summit. CA, USA, 16-18 May 2016 (Abstract D102).

35 Boyiadzis M, Agha M, Redner RL et al. Phase I clinical trial of adoptive immunotherapy using "off-the-shelf” activated natural killer cells (aNK) in patients with refractory/relapsed acute myeloid leukemia. Presented at: Annual Meeting of the American Society of Hematology. CA, USA, 3-6 December 2016.

36 Koerner SP, Andre MC, Leibold JS et al. An Fc-optimized CD133 antibody for induction of NK cell reactivity against myeloid leukemia. Leukemia 31(2), 459-469 (2016). 
37 Ruggeri L, Urbani E, Andre P et al. Effects of anti-NKG2A antibody administration on leukemia and normal hematopoietic cells. Haematologica 101(5), 626-633 (2016).

38 Morgan M, Dahlke J, Oberschmidt $\mathrm{O}$ et al. Targeting $\mathrm{CD}_{123^{+}}$acute myeloid leukemia cells with redirected natural killer cells. Presented at: 21st Congress of the European Hematology Association. Copenhagen, Denmark, 10 June 2016.

39 Klingemann H. Are natural killer cells superior CAR drivers? Oncoimmunology 3, e28147 (2014).

40 Rafiq S, Purdon TJ, Schultz LM, Klingemann H, Brentjens RJ. NK-92 cells engineered with anti-CD33 chimeric antigen receptors (CAR) for the treatment of acute myeloid leukemia (AML). Presented at: 21st ISCT Annual Meeting (International Society for Cellular Therapy). NV, USA, 27-30 May 2015.

$41 \mathrm{Niu} \mathrm{C}$, Jin $\mathrm{H}$, Li M et al. In vitro analysis of the proliferative capacity and cytotoxic effects of ex vivo induced natural killer cells, cytokine-induced killer cells, and gamma-delta T cells. BMC Immunology 16, 61 (2015).

42 Introna M, Borleri G, Conti $\mathrm{E}$ et al. Repeated infusions of donor-derived cytokine-induced killer cells in patients relapsing after allogeneic stem cell transplantation: a Phase I study. Haematologica 92(7), 952-959 (2007).

43 Guo Y, Han W. Cytokine-induced killer (CIK) cells: from basic research to clinical translation. Chin. J. Cancer 34(3), 99-107 (2015).

44 Wang Y, Bo J, Dai HR et al. CIK cells from recurrent or refractory AML patients can be efficiently expanded in vitro and used for reduction of leukemic blasts in vivo. Exp. Hematol. 41(3), 241-252 (2013).

45 Rettinger E, Huenecke S, Bonig H et al. Interleukin-15-activated cytokine-induced killer cells may sustain remission in leukemia patients after allogeneic stem cell transplantation: feasibility, safety and first insights on efficacy. Haematologica 101(4), e153-e156 (2016).

46 Tettamanti S, Marin V, Pizzitola I et al. Targeting of acute myeloid leukaemia by cytokine-induced killer cells redirected with a novel CD123-specific chimeric antigen receptor. Br. J. Haematol. 161(3), 389-401 (2013).

47 Fournie JJ, Sicard H, Poupot M et al. What lessons can be learned from gamma delta T cell-based cancer immunotherapy trials? Cell Mol. Immunol. 10(1), 35-41 (2013).

48 Gertner-Dardenne J, Castellano R, Mamessier E et al. Human V $\gamma 9 \mathrm{~V} \delta 2 \mathrm{~T}$ cells specifically recognize and kill acute myeloid leukemic blasts. J. Immunol. 188(9), 4701-4708 (2012).

49 Kunzmann V, Smetak M, Kimmel B et al. Tumor-promoting versus tumor-antagonizing roles of gamma delta T cells in cancer immunotherapy: results from a prospective Phase I/II trial. J. Immunol. 35(2), 205-213 (2012).

50 Berthon C, Driss V, Liu J et al. In acute myeloid leukemia, B7-H1 (PD-L1) protection of blasts from cytotoxic T cells is induced by TLR ligands and interferon-gamma and can be reversed using MEK inhibitors. Cancer Immunol. Immunother. 59(12), 1839-1849 (2010).

51 Liu H, Park JH, Fulton N et al. TCR clonal evolution in AML patients in morphologic remission treated with anti-PD1 antibody, nivolumab. Presented at: Annual Meeting of the American Society of Hematology. CA, USA, 3 December 2016.

52 Albring JC, Inselmann S, Sauer T et al. PD-1 checkpoint blockade in patients with relapsed AML after allogeneic stem cell transplantation. Bone Marrow Transplant. 52(2), 317-320 (2017).

53 Brunet JF, Denizot F, Luciani MF et al. A new member of the immunoglobulin superfamily - CTLA-4. Nature 328(6127), 267-270 (1987).

54 Saudemont A, Quesnel B. In a model of tumor dormancy, long-term persistent leukemic cells have increased B7-H1 and B7.1 expression and resist CTL-mediated lysis. Blood 104(7), 2124-2133 (2004).

55 Zhong RK, Loken M, Lane TA, Ball ED. CTLA-4 blockade by a human MAb enhances the capacity of AML-derived DC to induce T-cell responses against AML cells in an autologous culture system. Cytotherapy 8(1), 3-12 (2006).

56 Davids MS, Kim HT, Bachireddy P et al. Ipilimumab for patients with relapse after allogeneic transplantation. N. Engl. J. Med. 375(2), 143-153 (2016).

-. Validates the potential clinical efficacy of checkpoint inhibition for treatment of AML as demonstrated by some impressive responses, particularly in patients with extramedullary AML.

57 Goncalves Silva I, Gibbs BF, Bardelli M, Varani L, Sumbayev VV. Differential expression and biochemical activity of the immune receptor TIM-3 in healthy and malignant human myeloid cells. Oncotarget 6(32), 33823-33833 (2015).

58 Darwish NH, Sudha T, Godugu K et al. Acute myeloid leukemia stem cell markers in prognosis and targeted therapy: potential impact of BMI-1, TIM-3 and CLL-1. Oncotarget 7(36), 57811-57820 (2016).

59 Goncalves Silva I, Ruegg L, Gibbs BF et al. The immune receptor TIM-3 acts as a trafficker in a TIM-3/galectin-9 autocrine loop in human myeloid leukemia cells. Oncoimmunol. 5(7), e1195535 (2016).

60 Le Mercier I, Lines JL, Noelle RJ. Beyond CTLA-4 and PD-1, the generation Z of negative checkpoint regulators. Front. Immunol. 6, 418 (2015).

61 Kikushige Y, Miyamoto T. TIM-3 as a novel therapeutic target for eradicating acute myelogenous leukemia stem cells. Int. J. Hematol. 98(6), 627-633 (2013).

62 Bigalke I, Floisand Y, Solum G et al. AML patients in minimal residual disease vaccinated with a novel generation of fast dendritic cells expressing WT-1 and PRAME mount specific immune responses that relate to clinical outcome. Blood 126(23), 3798 (2015). 
63 Anguille S, Van de Velde AL, Smits EL et al. Dendritic cell vaccination as postremission treatment to prevent or delay relapse in acute myeloid leukemia. Blood 130(15), 1713-1721 (2017).

64 Kobayashi Y, Sakura T, Miyawaki S, Toga K, Sogo S, Heike Y. A new peptide vaccine OCV-501: in vitro pharmacology and Phase I study in patients with acute myeloid leukemia. Cancer Immunol. Immunother. 66(7), 851-863 (2017).

65 Maslak PG, Dao T, Bernal Y et al. Phase II trial of WT1 analog peptide vaccine in adults with acute myeloid leukemia (AML) in first complete remission (CR). Presented at: ASCO Annual Meeting. IL, USA, 3-7 June 2016.

66 Brayer J, Lancet JE, Powers J et al. WT1 vaccination in AML and MDS: a pilot trial with synthetic analog peptides. Am. J. Hematol. 90(7), 602-607 (2015).

67 Qazilbash MH, Wieder E, Thall PF et al. PR1 peptide vaccine induces specific immunity with clinical responses in myeloid malignancies. Leukemia 31(3), 697-704 (2017).

68 Counter CM, Gupta J, Harley CB, Leber B, Bacchetti S. Telomerase activity in normal leukocytes and in hematologic malignancies. Blood 85(9), 2315-2320 (1995).

69 Khoury HJ, Collins RH Jr, Blum W et al. Immune responses and long-term disease recurrence status after telomerase-based dendritic cell immunotherapy in patients with acute myeloid leukemia. Cancer 123(16), 3061-3072 (2017).

- Presents impressive data regarding safety and durability of human telomerase reverse transcriptase DC immunotherapy.

70 Rosenblatt J, Stone RM, Uhl L et al. DC/AML fusion cell vaccination administered to AML patients who achieve a complete remission potently expands leukemia reactive T cells and is associated with durable remissions. Blood 126(23), 2549 (2015).

71 Chevallier P, Saiagh S, Dehame V et al. A Phase I/II study of vaccination by autologous leukemic apoptotic corpse pulsed dendritic cells for elderly acute myeloid leukemia patients in first or second complete remission (LAM DC trial). Blood 128(22), 2821 (2016).

72 Lichtenegger F, Deiser K, Rothe M et al. Induction of antigen-specific T-cell responses through dendritic cell vaccination in AML: results of a Phase I/II trial and ex vivo enhancement by checkpoint blockade. Presented at: Annual Meeting of the American Society of Hematology. CA, USA, 5 December 2016. 